І. М. Кліщ, Н. Я. Потіха, Г. С. Сатурська, О. С. Ковалик

ДВНЗ “Тернопільський державний медичний університет

імені І. Я. Горбачевського МОЗ України”

\title{
КОМПЕТЕНТНІСНИЙ ПІДХІД ДО ПІДГОТОВКИ ДОКТОРІВ ФІЛОСОФІЇ У ДЕРЖАВНОМУ ВИЩОМУ НАВЧАЛЬНОМУ ЗАКЛАДІ “ТЕРНОПІЛЬСЬКИЙ ДЕРЖАВНИЙ МЕДИЧНИЙ УНІВЕРСИТЕТ ІМЕНІ І. Я. ГОРБАЧЕВСЬКОГО МІНІСТЕРСТВА ОХОРОНИ ЗДОРОВ'Я УКРАЇНИ”
}

\author{
I. M. Klishch, N. Ya. Potikha, H. S. Saturska, O. S. Kovalyk \\ I. Horbachevsky Ternopil State Medical University \\ THE COMPETENT APPROACH TO DOCTORS' OF PHILOSOPHY \\ TRAINING IN I. HORBACHEVSKY TERNOPIL STATE MEDICAL \\ UNIVERSITY
}

\begin{abstract}
Мета роботи - провести аналіз реалізації компетентнісного підходу до підготовки докторів філософії за освітньо-науковими програмами в Тернопільському державному медичному університеті і встановити відповідність його вимогам чинного законодавства України.

Основна частина. У ДВНЗ “Тернопільський державний медичний університет імені І. Я. Горбачевського МОЗ України” проводиться підготовка докторів філософії за ліцензованими спеціальностями галузі знань 22 “Охорона здоров”я”: 222 “Медицина”, 228 “Педіатрія”, 221 “Стоматологія”, 226 “Фармація” та за спеціальністю 091 “Біологія” галузі знань 09 “Біологія”. Підготовка фахівців третього (освітньо-наукового) рівня вищої освіти здійснюється на засадах компетентнісної парадигми за ліцензованими освітньо-науковими програмами та навчальними планами, затвердженими вченою радою університету. В освітньо-наукових програмах чітко окреслені визначення програмних компетентностей, які повинні здобуватися у процесі навчання докторами філософії (інтегральної, загальних та спеціальних). Освітньо-наукові програми підготовки докторів філософії включають у себе наукову та освітню складові і передбачають набуття чотирьох основних компетентностей відповідно до Національної рамки кваліфікацій: оволодіння загальнонауковими (філософськими) компетентностями; набуття універсальних навичок дослідника; здобуття мовних компетентностей; здобуття глибинних знань зі спеціальності, за якою аспірант проводить дослідження.

Висновки. У Тернопільському державному медичному університеті підготовка докторів філософії здійснюється відповідно до чинного законодавства України відповідно до розроблених освітньо-наукових програм у межах ліцензованих спеціальностей на засадах компетентнісного підходу до організації навчального процесу. Це сприяє цілеспрямованому формуванню необхідних компетенцій випускника, готовності їх до майбутньої успішної професійної діяльності, забезпечує цілісне бачення ними досліджуваної проблеми на основі її структурного аналізу.
\end{abstract}

Ключові слова: компетентності; доктор філософії; освітньо-наукова програма; наукова робота; навчальний процес.

The aim of the work - to analyze the implementation of a competent approach to the doctors' of philosophy training for educational and scientific programs in the Ternopil State Medical University and to establish compliance with its requirements of the current legislation of Ukraine.

The main body. The Doctors' of Philosophy training in the licensed specialties Medicine 222, Pharmacy 226, Dentistry 221, Pediatrics of the field of knowledge 228, Health Care 22 and Biology 091 speciality of the field of knowledge Biology 09 is carried out in I. Horbachevsky Ternopil State Medical University. Training of specialists of the third (educational-scientific) level of higher education is carried out on the basis of a competency paradigm on the basis of licensed educational and scientific programs and curricula approved by the Academic Council of the University. The definitions of program competencies that must be acquired by doctors of philosophy (integral, general and special) are clearly defined in educational programs. Educational and scientific programs for the preparation of doctors of philosophy include the scientific and educational components and involve the acquisition of four core competencies in accordance with the National Framework of Qualifications: mastering general scientific (philosophical) competencies; acquisition of universal skills of the researcher; obtaining of language competences; obtaining profound knowledge in the speciality on which the graduate student conducts research.

Conclusions. The Doctors' of Philosophy training is carried out in accordance with the current legislation of Ukraine in accordance with developed educational and scientific programs within the limits of licensed specialties on the basis of a competent approach to the organization of the educational process in the Ternopil State Medical University. It contributes to the purposeful formation of the necessary

() І. М. Кліщ, Н. Я. Потіха, Г. С. Сатурська, О. С. Ковалик 
competences of the graduate, their readiness for future successful professional activities, provides a coherent vision of the problem under study on the basis of its structural analysis.

Key words: competence; Doctor of Philosophy; educational-scientific program; scientific work; educational process.

Вступ. На сьогодні в Україні триває динамічний процес реформування освітньої системи, у тому числі медичної, з метою приведення вітчизняних критеріїв підготовки фахівців галузі знань “Охорона здоров’я” у відповідність до вимог міжнародної та європейської систем стандартів та сертифікації. Якісна підготовка фахівців на сучасному етапі $\epsilon$ неможливою без модернізації освітніх програм 3 урахуванням основних положень компетентнісного підходу, що сприятиме формуванню необхідних знань і вмінь у випускників вищих медичних закладів, підвищенню рівня їх конкурентоспроможності на ринку праці та готовності до успішної професійної діяльності [1]. В Україні впровадження компетентнісного підходу розглядається як шлях оновлення та інтеграції України до Європейського простору вищої освіти [2].

Нормативно компетентність розглядається як здатність особи до виконання певного виду діяльності, що виражається через знання, розуміння, уміння, цінності, інші особисті якості. Це динамічна комбінація знань, вмінь і практичних навичок, способів мислення, професійних, світоглядних і громадянських якостей, морально-етичних цінностей, яка визначає здатність особи успішно здійснювати професійну та подальшу навчальну діяльність і $\epsilon$ результатом навчання на певному рівні вищої освіти [3].

На думку Г. Селевка, компетентнісний підхід означає поступову переорієнтацію провідної освітньої парадигми з переважаючою трансляцією знань і формуванням навичок на створення умов для оволодіння комплексом компетенцій, які означають потенціал, здатність випускника до виживання i стійкої життєдіяльності в умовах сучасного багаточинникового соціально-політичного, ринково-економічного, інформаційно-комунікаційно насиченого простору [4]. Вважається, що компетентнісний підхід переміщує акценти із процесу накопичення нормативно визначених знань, умінь і навичок у площину формування й розвитку у фахівців здатності практично діяти і творчо застосовувати здобуті знання й набутий досвід у різних ситуаціях [5].

На сучасному етапі імплементації нового Закону “Про вищу освіту” є особливо актуальним питання якісної підготовки фахівців на третьому (освітньонауковому) рівні. Так, у статті 5 Закону України
“Про вищу освіту” окреслені нові поняття рівнів вищої освіти і встановлена їх відповідність рівням Національної рамки кваліфікацій. Зокрема: “третій (освітньо-науковий) рівень вищої освіти відповідає восьмому кваліфікаційному рівню Національної рамки кваліфікацій і передбачає здобуття особою теоретичних знань, умінь, навичок та інших компетентностей, достатніх для продукування нових ідей, розв'язання комплексних проблем у галузі професійної та/або дослідницько-інноваційної діяльності, оволодіння методологією наукової та педагогічної діяльності, а також проведення власного наукового дослідження, результати якого мають наукову новизну, теоретичне та практичне значення” [1].

Вища школа готує висококваліфіковані кадри для ринку праці, де набуті компетентності суворо перевіряються на практиці. Ступінь доктора філософії $є$ загальновизнаною кваліфікацією, яка забезпечує можливість подальшої викладацької та дослідницької діяльності [6]. Відповідно до дискрипторів Національної рамки кваліфікацій, доктор філософії повинен володіти найбільш передовими концептуальними та методологічними знаннями в галузі науково-дослідної та/або професійної діяльності і на межі предметних галузей, уміти проводити критичний аналіз, оцінку і синтез нових та складних ідей, спілкуватися в діалоговому режимі 3 широкою науковою спільнотою та громадськістю в певній галузі наукової та/або професійної діяльності, ініціювати інноваційні комплексні проекти, бути лідером та мати повну автономність під час реалізації проектів [3].

Мета роботи - провести аналіз реалізації компетентнісного підходу до підготовки докторів філософії за освітньо-науковими програмами в Тернопільському державному медичному університеті і встановити відповідність його вимогам чинного законодавства України.

Основна частина. У ДВНЗ “Тернопільський державний медичний університет імені І. Я. Горбачевського МОЗ України” проводиться підготовка докторів філософії за ліцензованими спеціальностями галузі знань 22 “Охорона здоров”я”: 222 “Медицина”, 228 “Педіатрія”, 221 “Стоматологія”, 226 “Фармація” та за спеціальністю 091 “Біологія” галузі знань 09 “Біологія”. Підготовка здобувачів вищої освіти ступеня доктора філософії здійснюється в 
аспірантурі за очною (денною, вечірньою) та заочною формами навчання, а також поза аспірантурою (для осіб, які професійно провадять науковопедагогічну діяльність за основним місцем роботи в університеті). Загальний ліцензований обсяг підготовки докторів філософії становить 95 осіб [7].

Підготовка фахівців третього (освітньо-наукового) рівня вищої освіти здійснюється відповідно до вимог Порядку підготовки здобувачів вищої освіти ступеня доктора філософії та доктора наук у вищих навчальних закладах (наукових установах), затвердженого Постановою Кабінету Міністрів України від 23.03.2016 р. № 261, за ліцензованими освітньонауковими програмами та навчальними планами, затвердженими вченою радою університету для кожної спеціальності [8].

В умовах реформування вищої медичної освіти в Україні вищим навчальним закладам і науковим установам на правах їх автономії та самоврядування надане право самостійно розробляти і впроваджувати власні освітні (освітньо-професійні чи освітньо-наукові) програми в межах ліцензованих спеціальностей, визначати зміст і наповнення програм навчальних дисциплін, вводити необхідні спеціалізації [1].

Освітньо-наукові програми підготовки докторів філософії розраховані на чотири академічних роки навчання. Загальний обсяг освітньої складової програми складає 48 кредитів Європейської кредитної трансферно-накопичувальної системи (ЄKTC), які здобувач наукового ступеня доктора філософії повинен опанувати протягом трьох років навчання. Освітньо-наукові програми визначають основний напрямок підготовки, обсяг кредитів, потрібний для здобуття відповідного освітньо-наукового рівня, перелік загальних та спеціальних (фахових) компетентностей, нормативний і варіативний зміст підготовки фахівця, вимоги до контролю якості вищої освіти. Усі навчальні плани аспірантури містять узгоджену нормативну частину (36 кредитів ЄKTC) та варіативну складову (12 кредитів ЄKТС).

В освітньо-наукових програмах чітко окреслені визначення програмних компетентностей, які повинні здобуватися у процесі навчання докторами філософії. Компетентності поділяють на інтегральні, загальні та спеціальні. Інтегральна компетентність це узагальнений опис кваліфікаційного рівня, який виражає основні компетентнісні характеристики рівня щодо навчання та/або професійної діяльності (пункт третій Національної рамки кваліфікацій, затвердженої Постановою Кабінету Міністрів Украї- ни від 23 листопада 2011 р. № 1341) [3]. Інтегральна компетентність, яка повинна здобутися докторами філософії, - це здатність розв’язувати комплексні проблеми професійної діяльності, проводити оригінальне наукове дослідження, здійснювати дослідницько-інноваційну діяльність у галузі охорони здоров’я/біології, що передбачає глибоке переосмислення наявних та створення нових цілісних знань/вмінь і їх практичне втілення.

Загальні компетентності - універсальні компетентності, що не залежать від предметної області, але важливі для успішної подальшої професійної та соціальної діяльності здобувача в його галузі та для його особистісного розвитку. Загальні компетентності доктора філософії включають в себе: здатність до підвищення професійної кваліфікації, здатність до пошуку, оброблення та аналізу інформації з різних джерел, здатність виявляти, ставити та вирішувати проблеми, генерувати ідеї, здатність розробляти та управляти проектами, здатність до спілкування у професійному середовищі та з представниками інших професій у національному та міжнародному контексті, здатність оцінювати та забезпечувати якість виконаних робіт.

Спеціальні (фахові, предметні) компетентності - компетентності, що залежать від предметної області та є важливими для успішної професійної діяльності за певною спеціальністю. Спеціальні (фахові) компетентності, які повинні здобуватися докторами філософії, включають в себе: здатність до розуміння предметної області за обраним науковим напрямом та освітньою діяльністю, здатність виявляти потребу в додаткових знаннях у сфері медицини та за напрямком наукових досліджень, генерувати наукові гіпотези, здатність формулювати дослідницьке питання, розробляти проект наукового дослідження, здатність обирати методи та кінцеві точки дослідження відповідно до мети та завдань наукового проекту, володіння сучасними методами наукового дослідження, здатність інтерпретувати результати наукових досліджень, проводити їх коректний аналіз та узагальнення, здатність до впровадження нових знань (наукових даних) в науку, освіту та інші сектори суспільства, здатність представляти результати наукових досліджень в усній і письмовій формах відповідно до національних та міжнародних стандартів, здатність до організації та реалізації педагогічної діяльності, здатність до лідерства, керування колективом, дотримання етики та академічної доброчесності. 
Освітньо-наукові програми підготовки докторів філософії включають у себе наукову та освітню складові і передбачають набуття чотирьох основних компетентностей відповідно до Національної рамки кваліфікацій $[3,8]$ :

1. Оволодіння загальнонауковими (філософськими) компетентностями, спрямованими на формування системного наукового світогляду, професійної етики та загального культурного кругозору (6 кредитів ЄКТС). 3 огляду на це, аспіранти вивчають предмети “Філософія науки”, “Академічна доброчесність”.

2. Набуття універсальних навичок дослідника, зокрема усної та письмової презентації результатів власного наукового дослідження українською мовою, застосування сучасних інформаційних технологій у науковій діяльності, організації та проведення навчальних занять, управління науковими проектами та/або складення пропозицій щодо фінансування наукових досліджень, реєстрації прав інтелектуальної власності (9 кредитів ЄКТС). Навчальним планом передбачено вивчення наступних предметів: “Методологія наукового дослідження”, "Педагогіка та психологія вищої школи з основами риторики”.

3. Здобуття мовних компетентностей, достатніх для представлення та обговорення результатів своєї наукової роботи іноземною мовою (англійською або іншою відповідно до специфіки спеціальності) в усній та письмовій формі, а також для повного розуміння іншомовних наукових текстів з відповідної спеціальності (6 кредитів ЄКТС). Дану компетентність здобувачі наукового ступеня доктора філософії здобувають у результаті вивчення дисципліни “Іноземна мова наукового спілкування".

4. Здобуття глибинних знань із спеціальності (групи спеціальностей), за якою (якими) аспірант (ад’юнкт) проводить дослідження, зокрема засвоєння основних концепцій, розуміння теоретичних і практичних проблем, історії розвитку та сучасного стану наукових знань за обраною спеціальністю, оволодіння термінологією з досліджуваного наукового напряму (15 кредитів ЄКТС). У цьому контексті відбувається засвоєння предметів "Клінічна епідеміологія та доказова медицина”, “Методологія і техніки інструментальних та лабораторних досліджень”, “Аналіз сучасних проблем та наукових напрямків в охороні здоров'я” тощо.
Варіативна частина навчальних планів розрахована на 12 кредитів і передбачає теоретичну та практичну підготовку за спеціальністю і спеціалізацією аспіранта. Вона спрямована на формування спеціальних компетентностей. Особливістю підготовки докторів філософії у галузі 22 “Охорона здоров’я” $\epsilon$ велика кількість спеціалізацій за кожною спеціальністю, що вимагає розробки окремих робочих програм із відповідних дисциплін.

Наукова складова освітньо-наукової програми передбачає проведення власного наукового дослідження під керівництвом наукового керівника та оформлення його результатів у вигляді дисертаційної роботи. Обовяязковим є підготовка та публікація наукових статей, оприлюднення результатів роботи на наукових конгресах, конференціях.

Висновки. У ДВНЗ “Тернопільський державний медичний університет імені І. Я. Горбачевського МОЗ України” підготовка докторів філософії здійснюється відповідно до чинного законодавства України відповідно до розроблених освітньо-наукових програм у межах ліцензованих спеціальностей на засадах компетентнісного підходу до організації навчального процесу. Компетентнісний підхід сприяє цілеспрямованому формуванню необхідних компетенцій випускника, готовності їх до майбутньої успішної професійної діяльності, забезпечує цілісне бачення ними досліджуваної проблеми на основі її структурного аналізу. У результаті побудови навчального процесу на засадах компетентнісної парадигми, з застосуванням інтегративного та міждисциплінарного підходів у дослідженнях сучасних наукових проблем, здобувачі освітньонаукового ступеня доктор філософії мають змогу проводити оригінальне наукове дослідження та здійснювати дослідницько-інноваційну діяльність на сучасному рівні.

Керівництво університету та науково-педагогічні кадри забезпечують усі необхідні умови ефективної організації освітньої та наукової складових освітньо-наукових програм підготовки докторів філософії. Перспективним напрямом подальшого вдосконалення підготовки докторів філософії $€$ розширення міжнародних програм співробітництва та програм міжнародної академічної мобільності. 


\section{Список літератури}

1. Про вищу освіту : Закон України від 01.07.2014 р. № 1556-VII [Електронний ресурс]. - Режим доступу : http://zakon.rada.gov.ua/laws/show/1556-18.

2. Внукова О. М. Педагогічна компетентність для здобувачів освітньо-наукового рівня вищої освіти / О. М. Внукова // Науковий часопис НПУ імені М. П. Драгоманова. Серія 16: Творча особистість учителя: проблеми теорії і практики. - 2016. - Вип. 26. C. 7-11.

3. Про затвердження Національної рамки кваліфікацій : Постанова Кабінету Міністрів України від 23 листопада 2011 р. № 1341 [Електронний ресурс]. - Режим доступу : http://zakon5.rada.gov.ua/laws/show/1341-2011-\%D0\%BF.

4. Селевко Г. Компетентности и их классификация / Г. Селевко // Народное образование. - 2004. - № 4. С. 138-143.

5. Химинець В. Компетентнісний підхід до професійного розвитку вчителя [Електронний ресурс] /

\section{References}

1. Pro vyshchu osvitu: zakon Ukrainy vid 01.07.2014 № 1556-VII [About higher education: the law of Ukraine 01.07.2014 № 1556-VII]. Retrieved from: http://zakon.rada. gov.ua/laws/show/1556-18 [in Ukrainian].

2. Vnukova, O.M. (2016). Pedahohichna kompetentnist dlia zdobuvachiv osvitno-naukovoho rivnia vyshchoi osvity [Pedagogical competence for applicants of the educationalscientific level of higher education]. Naukovyi chasopys NPU imeni M. P. Drahomanova. Seriia 16: Tvorcha osobystist uchytelia: problemy teorii i praktyky-Scientific Journal of N.P. Drahomanov NPU. Series 16: The Creative Personality of a Teacher: The Problems of Theory and Practice, 26, 7-11 [in Ukrainian].

3. Pro zatverdzhennia Natsionalnoi ramky kvalifikatsii: postanova Kabinetu Ministriv Ukrainy vid 23 lystopada 2011 r. № 1341 [About approval of the National Qualifications Framework: Decree of the Cabinet of Ministers of Ukraine 23.11.2011 p. № 1341]. Retrieved from: http:// zakon5.rada.gov.ua/laws/show/1341-2011-\%D0\%BF [in Ukrainian].

4. Selevko, H. (2004). Kompetentnosty i ikh klassyfykatsiya [Competencies and their classification]. Narodnoye obrazovanye - Folk Education, 4, 138-143 [in Russian].

5 . Khymynets, V. Kompetentnisnyi pidkhid do profesiinoho rozvytku vchytelia [Competent approach to professional development of a teacher]. Retrieved from: http://zakinppo. org.ua/2010-01-18-13-44-15/233-2010-08-25-07-10-49 [in Ukrainian].
В. Химинець. - Режим доступу : http://zakinppo.org. ua/2010-01-18-13-44-15/233-2010-08-25-07-10-49.

6. Сисоєва С. Підготовка докторів філософії у галузі освіти: досвід провідних університетів світу / С. Сисоєва, І. Регейло // Рідна школа. - 2016. - № 5-6. - С. 12-18.

7. Кліщ І. М. Досвід підготовки докторів філософії за освітньо-науковими програмами у Державному вищому навчальному закладі “Тернопільський державний медичний університет імені І. Я. Горбачевського Міністерства охорони здоров’я України” / I. М. Кліщ, Н. Я. Потіха, О. С. Ковалик // Медична освіта. - 2018. № 2 (78). - С. 121-124.

8. Про затвердження порядку підготовки здобувачів вищої освіти ступеня доктора філософії та доктора наук у вищих навчальних закладах (наукових установах) : Постанова Кабінету Міністрів України від 23.03.2016 р. № 261 [Електронний ресурс]. - Режим доступу : http:// zakon0.rada.gov.ua/laws/show/261-2016-\%D0\%BF.

6. Sysoieva, S., \& Reheilo, I. (2016). Pidhotovka doktoriv filosofii u haluzi osvity: dosvid providnykh universytetiv svitu [Training of Doctors of Philosophy in education: Experience of the leading universities of the world]. Ridna shkola - Native School, 5-6, 2-18 [in Ukrainian].

7. Klishch, I.M., Potikha, N.Ya., \& Kovalyk, O.S. (2018). Dosvid pidhotovky doktoriv filosofii za osvitno-naukovymy prohramamy u Derzhavnomu vyshchomu navchalnomu zakladi „Ternopilskyi derzhavnyi medychnyi universytet imeni I.Ya. Horbachevskoho Ministerstva okhorony zdorovia Ukrainy" [The experience of Doctors' of Philosophy training for educational and scientific programs in the State Institution of Higher Education "Ivan Horbachevsky Ternopil State Medical University of the Ministry of Health of Ukraine"]. Medychna osvita - Medical Education, 2 (78), 121-124 [in Ukrainian].

8. Pro zatverdzhennia poriadku pidhotovky zdobuvachiv vyshchoi osvity stupenia doktora filosofii ta doktora nauk u vyshchykh navchalnykh zakladakh (naukovykh ustanovakh): postanova Kabinetu Ministriv Ukrainy vid 23.03.2016 № 261 [On approval of the order of preparation of applicants for higher education for the degree of doctor of philosophy and doctor of sciences in higher educational establishments (scientific institutions)]. Retrieved from: http://zakon0.rada.gov.ua/laws/show/261-2016-\%D0\%BF [in Ukrainian]. 